\title{
Parapusillimonas granuli gen. nov., sp. nov., isolated from granules from a wastewater-treatment bioreactor
}

\author{
Correspondence \\ Deok-Chun Yang \\ deokchynyang@yahoo.co.kr
}

\author{
Yeon-Ju Kim, ${ }^{1}$ Myung Kyum Kim, ${ }^{2}$ Wan-Taek Im, $^{3}$ Sathiyaraj Srinivasan ${ }^{1}$ \\ and Deok-Chun Yang ${ }^{1}$
}
${ }^{1}$ Korean Ginseng Center and Ginseng Genetic Resource Bank, Kyung Hee University, 1 Seocheon- dong, Giheung-gu Yongin-si, Gyeonggi-do 449-701, Republic of Korea
${ }^{2}$ Department of Bio \& Environmental Technology, Division of Environmental \& Life Science, College of Natural Science, Seoul Women's University, 139-774, Republic of Korea
${ }^{3}$ Department of Biological Sciences, Korea Advanced Institute of Science and Technology, 373-1, Guseong-dong, Yuseong-gu, Daejeon 305-701, Republic of Korea

The family Alcaligenaceae is classified in the order of Burkholderiales in the class Betaproteobacteria and includes 17 genera, including Pusillimonas, Bordetella, Achromobacter and Alcaligenes (De Ley et al., 1986; Busse \& Auling, 1992).

Brownish-black granules (about $2 \mathrm{~mm}$ in diameter) from an upflow anaerobic sludge blanket (UASB) reactor, located in

Abbreviations: DPG, diphosphatidylglycerol; PE, phosphatidylethanolamine; $P G$, phosphatidylglycerol.

The GenBank/EMBL/DBBJ accession number for $16 \mathrm{~S}$ rRNA gene sequence of strain $\mathrm{ChO7}^{\top}$ is DQ466075.

Supplementary figures showing the production of fimbriae by strain $\mathrm{ChO7}^{\top}$, transmission electron micrographs of cells of strain $\mathrm{ChO}^{\top}$ and related strains, and the results of TLC analyses of polar lipids are available with the online version of this paper.
Daejeon, Korea, were homogenized by using an Ace Homogenizer (Nihonseiki Co.). The suspension was spread on R2A agar plates (Difco) after being serially diluted with $50 \mathrm{mM}$ phosphate buffer ( $\mathrm{pH} 7.0)$. The purified colonies were tentatively identified by partial sequences (1449 bp) of the $16 \mathrm{~S}$ rRNA gene. Strain $\mathrm{Ch} 7^{\mathrm{T}}$ was one of the isolates that appeared on the plates under aerobic conditions. In this study, strain $\mathrm{Ch} 07^{\mathrm{T}}$ was investigated using a polyphasic taxonomic approach, including a phylogenetic analysis based on 16S rRNA gene sequences, DNA-DNA hybridization and chemotaxonomic and phenotypic properties. The results revealed that strain $\mathrm{Ch} 07^{\mathrm{T}}$ could be assigned to a new genus in the family Alcaligenaceae.

Cell morphology and motility were observed using a light microscope $(\times 1000)$, with the cells being allowed to grow 
for 3 days at $30{ }^{\circ} \mathrm{C}$ on $\mathrm{R} 2 \mathrm{~A}$ agar. Colonies grown on R2A agar plates for 3 days were smooth and circular. For morphological observation with transmission electron microscopy, cells were grown on Luria-Bertani (LB; Difco LB broth) agar at $30{ }^{\circ} \mathrm{C}$ for $18 \mathrm{~h}$ and suspended bacterial cells were placed on carbon/Formvar-coated nickel grids for $30 \mathrm{~s}$. Grids were floated on one drop of $0.1 \%(\mathrm{w} / \mathrm{v})$ aqueous uranyl acetate, blotted dry and then observed with a Carl Zeiss LEO912AB electron microscope at $100 \mathrm{kV}$ under standard operating conditions. The Gram reaction was conducted according to the non-staining method as described by Buck (1982). Oxidase activity was evaluated via the oxidation of $1 \% p$-aminodimethylaniline oxalate and catalase activity was determined by measurements of bubble production after the application of $3 \%$ $(\mathrm{v} / \mathrm{v})$ hydrogen peroxide solution (Cappuccino \& Sherman, 2002). Growth at various temperatures $(4,15,25,30,37$ and $42{ }^{\circ} \mathrm{C}$ ) was assessed on R2A agar. Growth at different $\mathrm{pH}$ values ( $\mathrm{pH} 5.0-11.0$, at intervals of $0.5 \mathrm{pH}$ units) was assessed in R2A broth. Growth on nutrient agar (NA), LB agar and tryptic soy agar (TSA; BD) was also evaluated at $30{ }^{\circ} \mathrm{C}$. The API 20NE, API ID32 GN, API 50CH and API ZYM microtest systems were conducted at $30{ }^{\circ} \mathrm{C}$ according to the manufacturer's recommendations (bioMérieux). Anaerobic growth was determined on R2A agar supplemented with thioglycolate $(0.1 \%, \mathrm{w} / \mathrm{v})$ incubated at $28{ }^{\circ} \mathrm{C}$ for 10 days in a commercial system (GasPak EZ Gas Generating system, BD). Measurement of $\mathrm{H}_{2} \mathrm{~S}$ production was conducted on triple sugar-iron agar $(\mathrm{BBL})$ at $28{ }^{\circ} \mathrm{C}$ for 6 days.

Isoprenoid quinones were extracted with chloroform/ methanol $(2: 1, \mathrm{v} / \mathrm{v})$, purified by TLC and subsequently analysed by HPLC, as previously described by Collins \& Jones (1981) and Shin et al. (1996). For fatty acid analysis, strain $\mathrm{Ch}_{07}{ }^{\mathrm{T}}$ and the type strains of related species (Pusillimonas noertemannii $\mathrm{BN}^{\mathrm{T}}{ }^{\mathrm{T}}$, Achromobacter xylosoxidans subsp. xylosoxidans DSM $10346^{\mathrm{T}}$, Bordetella pertussis DSM $5571^{\mathrm{T}}$ ) were all incubated on TSA for $48 \mathrm{~h}$ at $28{ }^{\circ} \mathrm{C}$. Even though Pusillimonas noertemannii $\mathrm{BN}^{\mathrm{T}}$ grew more slowly than strain $\mathrm{Ch} 7^{\mathrm{T}}$ and showed only weak growth on TSA, the same amount of biomass $(50 \mathrm{mg})$ was collected for fatty acid analysis. Fatty acid methyl esters were identified with the Sherlock Microbial Identification System (MIDI) (Sasser, 1990). Polar lipids were extracted with chloroform/methanol $(2: 1, \mathrm{v} / \mathrm{v})$ and a $10 \mu \mathrm{l}$ sample was loaded on to the corners of two $10 \times 10 \mathrm{~cm}$ thin layer silica gel 60 plates (Merck) according to Bligh \& Dyer (1959). Polyamines were extracted and analysed according to Busse \& Auling (1988) and Schenkel et al. (1995).

DNA-DNA hybridizations were performed with photobiotin labelled probes in microplate wells as described by Ezaki et al. (1989), using an HTS7000 Bio Assay Reader (Perkin Elmer) for the fluorescence measurements. The hybridization temperature was $51{ }^{\circ} \mathrm{C}$. Reciprocal hybridization tests were performed in order to confirm the accuracy of the data. The highest and lowest values obtained for each sample were excluded and the means of the remaining three values are quoted as the final DNADNA hybridization values.

For the determination of the DNA G $+\mathrm{C}$ content, genomic DNA was extracted and purified with the Qiagen Genomictip system 100/G (Qiagen) and was then degraded into nucleosides by $\mathrm{P} 1$ nuclease. The nucleosides were analysed using HPLC as described previously by Tamaoka \& Komagata (1984) and Mesbah et al. (1989).

The 16S rRNA gene was amplified from the chromosomal DNA using the universal bacterial primer set, $\mathrm{fD} 1$ and $\mathrm{rP} 1$ (Weisburg et al., 1991) and the purified PCR product was sequenced by Genotec, Daejeon, Korea (Kim et al., 2005). The partial sequence of the $16 \mathrm{~S}$ rRNA gene was compiled with SeqMan software (DNASTAR Inc.). The 16S rRNA gene sequences of the related taxa were obtained from GenBank and edited using the BioEdit program (Hall, 1999). Multiple alignments were performed with the CLUSTAL_X program (Thompson et al., 1997). Evolutionary distances were calculated using the Kimura two-parameter model (Kimura, 1983). Phylogenetic trees were constructed by the neighbour-joining method (Saitou \& Nei, 1987) and with the maximum-parsimony method (Fitch, 1971) in the MEGA3 program (Kumar et al., 2001). A maximumlikelihood tree was also constructed using PHYLIP software (version 3.57c; Felsenstein, 1995). Bootstrap analysis with 1000 replicates was also performed in order to obtain confidence levels for the branches.

The 16S rRNA gene sequence of strain $\mathrm{Ch}^{\mathrm{T}} 7^{\mathrm{T}}$, a continuous stretch of 1449 nucleotides, was sequenced. Strain $\mathrm{Ch} 07^{\mathrm{T}}$ was found to belong to the family Alcaligenaceae. A search using the EzTaxon server (Chun et al., 2007) showed that it was closely related to Pusillimonas noertemannii $\mathrm{BN}^{\mathrm{T}}$ (gene sequence similarity $97.30 \%$ ), Achromobacter xylosoxidans subsp. xylosoxidans DSM $10346^{\mathrm{T}}(97.09 \%)$, Bordetella pertussis DSM $5571^{\mathrm{T}}$ (97.01\%), Pigmentiphaga kullae DSM $13608^{\mathrm{T}}(96.68 \%)$ and Castellaniella defragrans DSM $12141^{\mathrm{T}}$ $(96.47 \%)$. A closer relationship between strain $\mathrm{Ch} 07^{\mathrm{T}}$ and members of the genera Bordetella, Achromobacter, Pigmentiphaga, Castellaniella and Pusillimonas (Fig. 1) was suggested by the sequence comparison programs.

The DNA-DNA relatedness values for strain $\mathrm{Ch} 07^{\mathrm{T}}$ were relatively low with the type strains of Pusillimonas noertemannii (27.4\%), Achromobacter xylosoxidans subsp. xylosoxidans (44.7\%) and Bordetella pertussis (61.9\%). Reciprocal hybridization tests resulted in DNA-DNA relatedness values of $35.3, \quad 38.5$ and $57.8 \%$ with Pusillimonas noertemannii, Achromobacter xylosoxidans subsp. xylosoxidans and B. pertussis, respectively. These results confirmed that strain $C h 07^{\mathrm{T}}$ was a separate species at the genotype level according to the limits suggested by Wayne et al. (1987).

Members of the genera Alcaligenes, Achromobacter and Pigmentiphaga have DNA G $+\mathrm{C}$ contents ranging from 54 to $69 \mathrm{~mol} \%$. In contrast, members of the genera Oligella and Taylorella have relatively low $\mathrm{G}+\mathrm{C}$ contents of only 


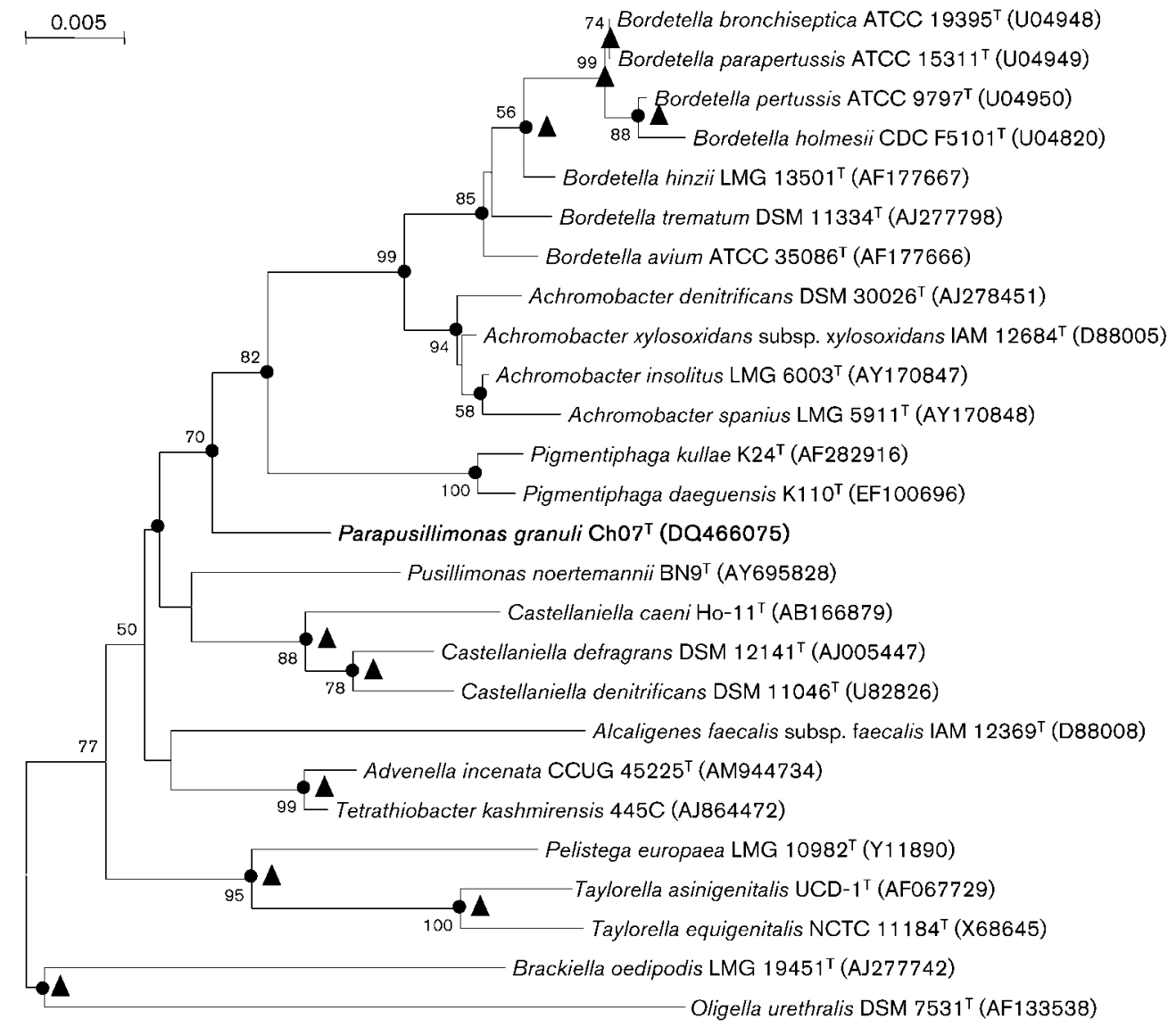

Fig. 1. Neighbour-joining tree, based on $16 \mathrm{~S}$ rRNA gene sequences, showing the phylogenetic relationships of strain Ch07 and representative members of the family Alcaligenaceae. Bootstrap values ( $>50 \%)$ based on 1000 replications are shown as percentages at branching points. Filled circles indicate that the corresponding nodes were also recovered in the tree generated with the maximum-parsimony algorithm. Filled triangles indicate that the corresponding nodes were also recovered in maximumlikelihood tree. Bar, 0.005 substitutions per nucleotide position.

36.5-47.5 mol\% (Busse \& Stolz, 2006). The DNA G+C content of strain $\mathrm{Ch}^{7}{ }^{\mathrm{T}}$ was determined to be $67.9 \pm 0.1 \mathrm{~mol} \%$.

Strain $\mathrm{Ch} 07^{\mathrm{T}}$ was found to be a facultatively anaerobic, Gram-negative, motile, short rod-shaped beige-coloured bacterium $(1.2-2.1 \mu \mathrm{m}$ in length and $0.3-0.9 \mu \mathrm{m}$ in diameter). Cells of the strain produced fimbriae $(7-8 \mathrm{~nm}$ in width; see Supplementary Fig. S1, available in IJSEM Online) and had three flagella (see Supplementary Fig. S2). Compared with those of Achromobacter xylosoxidans subsp. xylosoxidans DSM $10346^{\mathrm{T}}$ and Bordetella pertussis DSM $5571^{\mathrm{T}}$, the flagella of strain $\mathrm{Ch} 7^{\mathrm{T}}$ and Pusillimonas noertemannii $\mathrm{BN}^{\mathrm{T}}$ were easily lost during sample preparation for microscope observation. Strain $\mathrm{Ch}^{\mathrm{T}}$ and Achromobacter xylosoxidans subsp. xylosoxidans DSM $10346^{\mathrm{T}}$ were able to grow under anaerobic conditions, whereas other closely related strains such as Pusillimonas noertemannii $\mathrm{BN}^{\mathrm{T}}$ and Bordetella pertussis DSM $5571^{\mathrm{T}}$ were unable to grow anaerobically. The results of comparisons of differential characteristics between strain
$\mathrm{Ch} 07^{\mathrm{T}}$ and related type strains are summarized in Table 1 and Table 2.

The cellular fatty acid profiles of strain $\mathrm{Ch} 07^{\mathrm{T}}$ and related strains are shown in Table 2. When strain $C h 07^{\mathrm{T}}$ was cultivated on TSA, the major cellular fatty acids were similar to those found when the strain was cultivated on NA. The affiliation of strain $C h 07^{\mathrm{T}}$ to the family Alcaligenaceae was unambiguously demonstrated by $16 \mathrm{~S}$ rRNA gene sequence comparisons and phylogenetic analyses. However, the fatty acid profile of strain $\mathrm{Ch} 07^{\mathrm{T}}$ [absence of hydroxy fatty acids and presence of summed feature $\left.5 \quad\left(\mathrm{C}_{18: 1} \omega 7 c / \omega 9 t / \omega 12 t\right)\right]$ easily differentiated the novel strain from Pusillimonas noertemannii $\mathrm{BN}^{\mathrm{T}}$. The growth of Pusillimonas noertemannii $\mathrm{BN}^{\mathrm{T}}$ and Bordetella pertussis DSM $5571^{\mathrm{T}}$ was slightly slower on NA when compared with that of strain $\mathrm{Ch} 07^{\mathrm{T}}$ and Achromobacter xylosoxidans subsp. xylosoxidans DSM $10346^{\mathrm{T}}$. The composition of fatty acids in Pusillimonas noertemannii $\mathrm{BN}^{\mathrm{T}}$ determined in this study was different from those previously reported by Stolz et al. (2005). The report of 
Table 1. Differential phenotypic characteristics between strain $\mathrm{ChO} 7^{\top}$ and related type strains

Strains: 1, Parapusillimonas granuli $\mathrm{Ch}^{\mathrm{T}}{ }^{\mathrm{T}} ; 2$, Pusillimonas noertemannii $\mathrm{BN} 9^{\mathrm{T}}$; 3 , Achromobacter xylosoxidans sub. xylosoxidans DSM $10346^{\mathrm{T}}$; 4 , Bordetella pertussis DSM $5571^{\mathrm{T}}$. All the strains had Q8 as the major isoprenoid quinone, showed positive activities for urease and esterase (C4) and assimilated D-glucose, malate, citrate, propionic acid, L-proline, L-serine and valeric acid. All strains gave a negative result in tests for the following: indole production, reduction of nitrates to nitrites and activities of $\alpha$-fucosidase, $\alpha$-mannosidase, $N$ acetyl- $\beta$-glucosaminidase, $\alpha$-glucosidase, $\beta$-glucosidase, $\beta$-glucuronidase, $\beta$-galactosidase, $\alpha$-chymotrypsin, trypsin and lipase (C14). Assimilation of the following is negative for all strains: L-arabinose, L-fucose, melibiose, salicin, D-mannitol, maltose, mannose, arabinose, sucrose, inositol, D-ribose, L-rhamnose, glycogen, potassium 5-ketogluconate, sodium malonate, $N$-acetyl-D-glucosamine, $p$-nitrophenyl- $\beta$-D-galactopyranoside and gelatin. All strains are weakly positive for valine arylamidase. +, Positive; -, negative; $\mathrm{w}$, weakly positive. All data are from this study.

\begin{tabular}{|c|c|c|c|c|}
\hline Characteristic & 1 & 2 & 3 & 4 \\
\hline Cell size $(\mu \mathrm{m})$ & $0.9 \times 1.5$ & $0.7 \times 1.1$ & $0.7 \times 1.5$ & $0.8 \times 1.4$ \\
\hline Flagella (number) & 3 & 2 & 1 & 1 \\
\hline $\mathrm{H}_{2} \mathrm{~S}$ production & - & - & + & - \\
\hline Growth in anaerobic conditions & + & - & + & - \\
\hline \multicolumn{5}{|l|}{ Enzyme activities } \\
\hline Acid phosphatase & - & - & + & - \\
\hline Alkaline phosphatase & - & - & $\mathrm{w}$ & - \\
\hline Arginine dihydrolase & + & $\mathrm{w}$ & + & + \\
\hline Cystine arylamidase & - & - & - & - \\
\hline$\alpha$-Galactosidase & - & - & $\mathrm{W}$ & - \\
\hline Leucine arylamidase & + & - & $\mathrm{W}$ & $\mathrm{W}$ \\
\hline Lipase (C8) & + & - & - & $\mathrm{W}$ \\
\hline Naphthol-AS-BI-phosphohydrolase & - & $\mathrm{w}$ & + & $\mathrm{w}$ \\
\hline Acidification of glucose & + & - & + & - \\
\hline \multicolumn{5}{|l|}{ Assimilation of } \\
\hline Adipate & + & - & + & - \\
\hline L-Alanine & + & - & w & - \\
\hline Caprate & - & - & + & - \\
\hline Gluconate & + & - & + & $\mathrm{w}$ \\
\hline L-Histidine & $\mathrm{w}$ & $\mathrm{w}$ & - & + \\
\hline 3-Hydroxybenzoic acid & + & + & - & + \\
\hline 4-Hydroxybenzoic acid & + & + & - & + \\
\hline 3-Hydroxybutyric acid & + & + & - & + \\
\hline Itaconic acid & $\mathrm{w}$ & + & - & - \\
\hline Lactic acid & + & + & $\mathrm{W}$ & - \\
\hline Phenylacetate & + & - & + & - \\
\hline Potassium 2-ketogluconate & + & - & - & $\mathrm{w}$ \\
\hline Sodium acetate & + & + & $\mathrm{w}$ & - \\
\hline D-Sorbitol & + & - & - & - \\
\hline Suberic acid & - & + & + & + \\
\hline DNA G $+\mathrm{C}$ content $(\mathrm{mol} \%)^{*}$ & 67.9 & $61.8^{a}$ & $69.2^{b}$ & $63.8^{c}$ \\
\hline
\end{tabular}

${ }^{\star}$ Data from: $a$, Stolz et al. (2005); b, Yabuuchi \& Yano (1981) and c, Vancanneyt et al. (1995).

Stolz et al. (2005) showed Pusillimonas noertemannii BN9 ${ }^{\mathrm{T}}$ contained large amounts of $\mathrm{C}_{16: 0}(19 \%), \mathrm{C}_{17: 0}$ cyclo $(31 \%)$ and $\mathrm{C}_{19: 0}$ cyclo $8 c(27 \%)$. However, our results showed the following fatty acid content: $\mathrm{C}_{16: 0}(19.7 \%)$, $\mathrm{C}_{17: 0}$ cyclo $(18.8 \%)$, summed feature $3\left(\mathrm{C}_{16: 1} \omega 7 c / \mathrm{C}_{15: 0}\right.$ iso $2-\mathrm{OH} ; 5.3 \%)$ and summed feature $5\left(\mathrm{C}_{18: 1} \omega 7 \mathrm{c} / \omega 9 \mathrm{t} /\right.$ $\omega 12 t)$ was not detected. The quantitative differences in fatty acid contents found between this study and previous studies may have been due to the use of biomass harvested from different incubation conditions and at different growth phases.

The predominant quinone of strain $\mathrm{Ch}_{0}{ }^{\mathrm{T}}$ was Q-8. This quinone system supported our assignment of strain $\mathrm{Ch}_{07}{ }^{\mathrm{T}}$ to the order Burkholderiales as most of the species in this order also exhibit Q-8 as the predominant quinone. Strain $\mathrm{Ch} 07^{\mathrm{T}}$ possessed polar lipids such as phosphatidylethanolamine (PE), phosphatidylglycerol (PG) and diphosphati- 
Table 2. Cellular fatty acid composition (\%) of strain $\mathrm{ChO}^{\top}$ and related type strains

Strains: 1, Parapusillimonas granuli $\mathrm{Ch}_{0}{ }^{\mathrm{T}} ; 2$, Pusillimonas noertemannii $\mathrm{BN}^{\mathrm{T}}$; 3 , Achromobacter xylosoxidans subsp. xylosoxidans DSM $10346^{\mathrm{T}} ; 4$, Bordetella pertussis DSM $5571^{\mathrm{T}}$. All strains were grown on TSA at $30{ }^{\circ} \mathrm{C}$ for $48 \mathrm{~h}$ prior to fatty acid analysis. For unsaturated fatty acids, the position of the double bond is located by counting from the methyl $(\omega)$ end of the carbon chain. The cis and trans isomers are indicated by the suffixes $c$ and $t$, respectively. ND, not detected; tr, trace amount $<0.5 \%$.

\begin{tabular}{|lcccc|}
\hline Fatty acid & $\mathbf{1}$ & $\mathbf{2}$ & $\mathbf{3}$ & $\mathbf{4}$ \\
\hline Saturated & & & & \\
$\mathrm{C}_{12: 0}$ & $\mathrm{ND}$ & 5.9 & 1.4 & 3.8 \\
$\mathrm{C}_{14: 0}$ & $\mathrm{ND}$ & 2.7 & 2.1 & $\mathrm{tr}$ \\
$\mathrm{C}_{16: 0}$ & 33.2 & 19.7 & 37.2 & 14.8 \\
$\mathrm{C}_{17: 0}$ cyclo & 18.2 & 18.8 & 8.3 & 16.9 \\
$\mathrm{C}_{18: 0}$ & $\mathrm{tr}$ & 2.4 & 2.7 & 4.7 \\
$\mathrm{C}_{19: 0}$ cyclo $\omega 8 c$ & $\mathrm{ND}$ & 13.6 & $\mathrm{tr}$ & $\mathrm{ND}$ \\
$\mathrm{C}_{19: 0} 10$ methyl TBSA & $\mathrm{ND}$ & $\mathrm{ND}$ & $\mathrm{ND}$ & 9.9 \\
Unsaturated $_{\mathrm{C}_{14: 1} \omega 5 c}$ & & & & \\
$\mathrm{C}_{18: 1} \omega 7 c$ & $\mathrm{ND}$ & 1.2 & $\mathrm{ND}$ & $\mathrm{ND}$ \\
$\mathrm{C}_{18: 1} \omega 9 c$ & $\mathrm{ND}$ & 5.0 & 8.9 & 2.9 \\
$\mathrm{C}_{19: 0}$ cyclo $\omega 8 c$ & $\mathrm{ND}$ & 2.8 & $\mathrm{tr}$ & 6.5 \\
$\mathrm{C}_{20: 2} \omega 6,9 c$ & 0.9 & $\mathrm{ND}$ & $\mathrm{tr}$ & 15.8 \\
$\mathrm{H}_{\text {Hydroxy }}$ & $\mathrm{ND}$ & 0.9 & $\mathrm{ND}$ & $\mathrm{ND}$ \\
$\mathrm{C}_{12: 0} 2-\mathrm{OH}$ & & & & \\
$\mathrm{C}_{14: 0} 2-\mathrm{OH}$ & $\mathrm{ND}$ & 3.3 & 1.6 & 2.6 \\
$\mathrm{C}_{16: 0} 3-\mathrm{OH}$ & $\mathrm{ND}$ & $\mathrm{ND}$ & $\mathrm{ND}$ & 1.8 \\
$\mathrm{C}_{18: 1} 2-\mathrm{OH}$ & $\mathrm{ND}$ & 1.51 & $\mathrm{tr}$ & 1.6 \\
Summed features & $\mathrm{ND}$ & 3.7 & $\mathrm{ND}$ & 2.2 \\
2 & & & & \\
3 & 7.4 & 13.4 & 9.8 & 6.8 \\
5 & 28.5 & 5.3 & 25.9 & 2.9 \\
& 11.3 & $\mathrm{ND}$ & $\mathrm{ND}$ & $\mathrm{ND}$ \\
\hline
\end{tabular}

* Summed features are groups of two or three fatty acids that cannot be separated by GLC with the MIDI system. Summed feature 2 contains $\mathrm{C}_{16: 1}$ isoI/ $\mathrm{C}_{14: 0} 3-\mathrm{OH}$ and/or $\mathrm{C}_{12: 0}$ alde. Summed feature 3 contains $\mathrm{C}_{16: 1} \omega 7 c / \mathrm{C}_{15: 0}$ iso 2-OH. Summed feature 5 contains $\mathrm{C}_{18: 1} \omega 7 c / \omega 9 t / \omega 12 t$.

dylglycerol (DPG), which are common in members of the genera Pusillimonas, Alcaligenes and Castellaniella of the family Alcaligenaceae (see Supplementary Fig. S3, available in IJSEM online). Pusillimonas noertemannii $\mathrm{BN}^{\mathrm{T}}$ was found to contain polar lipids PE, DPG and PG and the results from this study were similar to those found by Stolz et al. (2005). The major polyamine of the strain $\mathrm{Ch} 07^{\mathrm{T}}$ was putrescine, which is a common feature of members of the class Betaproteobacteria.

On the basis of phylogenetic and chemotaxonomic data, strain $\mathrm{Ch} 07^{\mathrm{T}}$ was clearly different from strains belonging to the genera Pusillimonas, Achromobacter and Bordetella. It is proposed that the strain $C h 07^{\mathrm{T}}$ represents a novel species of a new genus. The name Parapusillimonas granuli gen. nov., sp. nov. is proposed for this new taxon.

\section{Description of Parapusillimonas gen. nov.}

Parapusillimonas (Pa.ra.pu.sil.li.mo'nas. Gr. prep. para like; N.L. fem. n. Pusillimonas bacterial genus name; N.L. fem. $\mathrm{n}$. Parapusillimonas a bacterium like Pusillimonas).

Cells are Gram-reaction-negative. Tests for catalase and oxidase are positive. Ubiquinone Q-8 is present. When incubated on TSA, the major cellular fatty acids are $\mathrm{C}_{16: 0}$, $\mathrm{C}_{17: 0}$ cyclo, summed feature $3\left(\mathrm{C}_{16: 1} \omega 7 c / \mathrm{C}_{15: 0}\right.$ iso 2-OH $)$ and summed feature $5\left(\mathrm{C}_{18: 1} \omega 7 \mathrm{c} / \omega 9 t / \omega 12 t\right)$. The major polyamine is putrescine. The polar lipids are PE, PG and DPG. The $\mathrm{G}+\mathrm{C}$ content of the genomic DNA is high $(67.9 \pm 0.1 \mathrm{~mol} \%)$. The type species of the genus is Parapusillimonas granuli.

\section{Description of Parapusillimonas granuli sp. nov.}

Parapusillimonas granuli (gra.nu'li. L. gen. n. granuli of a small grain, pertaining to a granule, from which the type strain was isolated).

Facultatively anaerobic, short rods $(0.9 \mu \mathrm{m} \times 1.5 \mu \mathrm{m})$. Cells are motile by means of three flagella per cell. Fimbriae $(\Phi 7.56 \mathrm{~nm})$ are located on the cell surface. When grown on $\mathrm{R} 2 \mathrm{~A}$ agar at $30{ }^{\circ} \mathrm{C}$ for 5 days, colonies of the type strain are beige-coloured and circular and have a diameter of about $2 \mathrm{~mm}$. Grows on R2A agar at $25-37{ }^{\circ} \mathrm{C}$ and at $\mathrm{pH}$ 6.5-7.5. The optimal growth temperature and $\mathrm{pH}$ are $30{ }^{\circ} \mathrm{C}$ and $\mathrm{pH} 7$, respectively. Produces arginine dihydrolase, urease, esterase $(\mathrm{C} 4)$, esterase $(\mathrm{C} 8)$, leucine arylamidase and valine arylamidase. Gives a negative result in tests for the following: production of $\mathrm{H}_{2} \mathrm{~S}$ and indole, reduction of nitrates to nitrites and activities of $\beta$-glucosidase, $\alpha$ glucosidase, $\beta$-galactosidase, $\alpha$-galactosidase, $\beta$-glucuronidase, alkaline phosphatase, acid phosphatase, protease, cystine arylamidase, naphthol-AS-BI-phosphohydrolase, $\alpha$-fucosidase, $\alpha$-mannosidase, $N$-acetyl- $\beta$-glucosaminidase, $\alpha$-chymotrypsin, trypsin and lipase (C14). Assimilates Dglucose, D-sorbitol, adipate, phenylacetate, sodium acetate, lactic acid, 3-hydroxybenzoic acid, 4-hydroxybenzoic acid, 3-hydroxybutyric acid, potassium 2-ketogluconate, malate, citrate, propionic acid, valeric acid, L-proline, L-alanine, Lserine, L-histidine and gluconate. Does not assimilate Larabinose, caprate, L-fucose, melibiose, maltose, D-mannitol, sucrose, inositol, D-ribose, L-rhamnose, salicin, glycogen, potassium 5-ketogluconate, sodium malonate or suberic acid. The predominant quinone is Q-8.

The type strain, $\mathrm{Ch} 07^{\mathrm{T}}\left(=\mathrm{KCTC} 12668^{\mathrm{T}}=\mathrm{LMG} 24012^{\mathrm{T}}\right)$, was isolated from brownish-black granules from an upflow anaerobic sludge blanket reactor used to treat brewery wastewater, Daejeon, Republic of Korea. The DNA G + C content of the type strain is $67.9 \pm 0.1 \mathrm{~mol} \%$, as determined by HPLC.

\section{Acknowledgements}

This study was supported by a grant from the Kyung Hee University Post-Doctoral fellowship (KHU-20090444) and GRCMVP for 
Technology Development Program of Agriculture and Forestry, Ministry of Agriculture and Forestry, Republic of Korea.

\section{References}

Bligh, E. G. \& Dyer, W. J. (1959). A rapid method of total lipid extraction and purification. Can J Biochem Physiol 37, 911-917.

Buck, J. D. (1982). Nonstaining (KOH) method for determination of Gram reactions of marine bacteria. Appl Environ Microbiol 44, 992993.

Busse, H.-J. \& Auling, G. (1988). Polyamine pattern as a chemotaxonomic marker within the Proteobacteria. Syst Appl Microbiol 11, 1-8.

Busse, J. \& Auling, G. (1992). The genera Alcaligenes and 'Achromobacter'. In The Prokaryotes, 2nd edn, pp. 2544-2555. Edited by A. Balows, H. G. Trüper, M. Dworkin, W. Harder \& K.-H. Schleifer. New York: Springer.

Busse, H.-J. \& Stolz, A. (2006). Achromobacter, Alcaligenes and related genera. In The Prokaryotes: a Handbook on the Biology of Bacteria, 3rd edn, pp. 675-700. Edited by M. Dworkin, S. Falkow, E. Rosenberg, K. H. Schleifer \& E. Stackebrandt. New York: Springer.

Cappuccino, J. G. \& Sherman, N. (2002). Microbiology: a laboratory manual, 6th edn. Pearson Education, Inc. Benjamin Cummings, CA.

Chun, J., Lee, J.-H., Jung, Y., Kim, M., Kim, S., Kim, B. K. \& Lim, Y. W. (2007). EzTaxon: a web-based tool for the identification of prokaryotes based on 16S ribosomal RNA gene sequences. Int J Syst Evol Microbiol 57, 2259-2261.

Collins, M. D. \& Jones, D. (1981). Distribution of isoprenoid quinone structural types in bacteria and their taxonomic implications. Microbiol Rev 45, 316-354.

De Ley, J., Segers, P., Kersters, K., Mannheim, W. \& Lievens, A. (1986). Intra- and intergeneric similarities of the Bordetella ribosomal ribonucleic acid cistrons: proposal for a new family, Alcaligenaceae. Int J Syst Bacteriol 36, 405-414.

Ezaki, T., Hashimoto, Y. \& Yabuuchi, E. (1989). Fluorometric deoxyribonucleic acid-deoxyribonucleic acid hybridization in microdilution wells as an alternative to membrane filter hybridization in which radioisotopes are used to determine genetic relatedness among bacterial strains. Int J Syst Bacteriol 39, 224-229.

Felsenstein, J. (1995). PHYLIP (Phylogeny Inference Package) and manual, version 3.57c. Department of Genetics, University of Washington, Seattle, WA, USA.

Fitch, W. M. (1971). Toward defining the course of evolution: minimum change for a specific tree topology. Syst Zool 20, 406-416.

Hall, T. A. (1999). BioEdit: a user-friendly biological sequence alignment editor and analysis program for Windows 95/98/NT. Nucleic Acids Symp Ser 41, 95-98.

Kim, M. K., Im, W.-T., Ohta, H., Lee, M. \& Lee, S.-T. (2005). Sphingopyxis granuli sp. nov., a $\beta$-glucosidase-producing bacterium in the family Sphingomonadaceae in $\alpha-4$ subclass of the Proteobacteria. J Microbiol 43, 152-157.

Kimura, M. (1983). The Neutral Theory of Molecular Evolution. Cambridge: Cambridge University Press.

Kumar, S., Tamura, K., Jakobsen, I. B. \& Nei, M. (2001). MEGA2: Molecular evolutionary genetics analysis software. Bioinformatics 17, 1244-1245.

Mesbah, M., Premachandran, U. \& Whitman, W. B. (1989). Precise measurement of the $\mathrm{G}+\mathrm{C}$ content of deoxyribonucleic acid by highperformance liquid chromatography. Int J Syst Bacteriol 39, 159-167.

Saitou, N. \& Nei, M. (1987). The neighbor-joining method: a new method for reconstructing phylogenetic trees. Mol Biol Evol 4, 406425.

Sasser, M. (1990). Identification of bacteria by gas chromatography of cellular fatty acids. MIDI Technical Note 101. Newark, DE: MIDI Inc.

Schenkel, E., Berlaimont, V., Dubois, J., Helson-Cambier, M. \& Hanocq, M. (1995). Improved high-performance liquid chromatographic method for the determination of polyamines as their benzoylated derivatives: application to P388 cancer cells. J Chromatogr B Biomed Appl 668, 189-197.

Shin, Y. K., Lee, J.-S., Chun, C. O., Kim, H.-J. \& Park, Y.-H. (1996). Isoprenoid quinone profiles of the Leclercia adecarboxylata KCTC $1036^{\mathrm{T}}$. J Microbiol Biotechnol 6, 68-69.

Stolz, A., Bürger, S., Kuhm, A., Kämpfer, P. \& Busse, H.-J. (2005). Pusillimonas noertemannii gen. nov., sp. nov., a new member of the family Alcaligenaceae that degrades substituted salicylates. Int J Syst Evol Microbiol 55, 1077-1081.

Tamaoka, J. \& Komagata, K. (1984). Determination of DNA base composition by reversed-phase high-performance liquid chromatography. FEMS Microbiol Lett 25, 125-128.

Thompson, J. D., Gibson, T. J., Plewniak, F., Jeanmougin, F. \& Higgins, D. G. (1997). The CLUSTAL_X windows interface: flexible strategies for multiple sequence alignment aided by quality analysis tools. Nucleic Acids Res 25, 4876-4882.

Vancanneyt, M., Vandamme, P. \& Kersters, K. (1995). Differentiation of Bordetella pertussis, B. parapertussis, and B. bronchiseptica by wholecell protein electrophoresis and fatty acid analysis. Int J Syst Bacteriol 45, 843-847.

Wayne, L. G., Brenner, D. J., Colwell, R. R., Grimont, P. A. D., Kandler, O., Krichevsky, M. I., Moore, L. H., Moore, W. E. C., Murray, R. G. E. \& other authors (1987). International Committee on Systematic Bacteriology. Report of the ad hoc committee on reconciliation of approaches to bacterial systematics. Int J Syst Bacteriol 37, 463-464.

Weisburg, W. G., Barns, S. M., Pelletier, D. A. \& Lane, D. J. (1991). 16 S ribosomal DNA amplification for phylogenetic study. J Bacteriol 173, 697-703.

Yabuuchi, E. \& Yano, I. (1981). Achromobacter gen. nov. and Achromobacter xylosoxidans (ex Yabuuchi and Ohyama 1971) nom. rev. Int J Syst Bacteriol 31, 477-478. 